\title{
Coronavirus disease 2019 and its potential animal reservoirs: A review
}

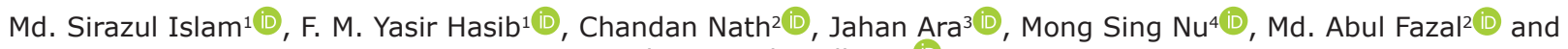 \\ Sharmin Chowdhury ${ }^{1}$ (i)
}

1. Department of Pathology and Parasitology, Faculty of Veterinary Medicine, Chattogram Veterinary and Animal Sciences University, Chattogram, Bangladesh; 2. Department of Microbiology and Veterinary Public Health, Faculty of Veterinary Medicine, Chattogram Veterinary and Animal Sciences University, Chattogram, Bangladesh; 3. One Health Institute, Chattogram Veterinary and Animal Sciences University, Chattogram, Bangladesh; 4. Department of Physiology, Biochemistry and Pharmacology, Faculty of Veterinary Medicine Chattogram Veterinary and Animal Sciences University, Chattogram, Bangladesh.

Corresponding author: Jahan Ara, e-mail: jahan78621@yahoo.com

Co-authors: MSI: sirazul@yahoo.com,FMYH: fmyhasib@gmail.com, CN: chandannath227@gmail.com, MSN: dr.mongsing@gmail.com, MAF: sorputi@gmail.com, SC: sharminchowdhury77@gmail.com

Received: 17-12-2020, Accepted: 15-06-2021, Published online: 25-08-2021

doi: www.doi.org/10.14202/IJOH.2021.171-181 How to cite this article: Islam MS, Hasib FMY, Nath C, Ara J, Nu MS, Fazal MA, Chowdhury S (2021) Coronavirus disease 2019 and its potential animal reservoirs: A review, Int. J. One Health, 7(2): 171-181.

\begin{abstract}
In the $21^{\text {st }}$ century, the world has been plagued by coronavirus disease 2019 (COVID-19) caused by severe acute respiratory syndrome coronavirus 2 (SARS-CoV-2), a virus of the family Coronaviridae epidemiologically suspected to be linked to a wet market in Wuhan, China. The involvement of wildlife and wet markets with the previous outbreaks simultaneously has been brought into sharp focus. Although scientists are yet to ascertain the host range and zoonotic potential of SARSCoV-2 rigorously, information about its two ancestors, SARS-CoV and Middle East respiratory syndrome coronavirus (MERS-CoV), is a footprint for research on COVID-19. A 96\% genetic similarity with bat coronaviruses and SARS$\mathrm{CoV}-2$ indicates that the bat might be a potential reservoir of SARS-CoV-2 just like SARS-CoV and MERS-CoV, where civets and dromedary camels are considered the potential intermediate host, respectively. Perceiving the genetic similarity between pangolin coronavirus and SARS-CoV-2, many scientists also have given the scheme that the pangolin might be the intermediate host. The involvement of SARS-CoV-2 with other animals, such as mink, snake, and turtle has also been highlighted in different research articles based on the interaction between the key amino acids of S protein in the receptorbinding domain and angiotensin-converting enzyme II (ACE2). This study highlights the potential animal reservoirs of SARS-CoV-2 and the role of wildlife in the COVID-19 pandemic. Although different causes, such as recurring viral genome recombination, wide genetic assortment, and irksome food habits, have been blamed for this emergence, basic research studies and literature reviews indicate an enormous consortium between humans and animals for the COVID-19 pandemic.
\end{abstract}

Keywords: ACE2 receptor, COVID-19, Intermediate host, SARS-CoV-2, wildlife.

\section{Introduction}

Coronaviruses are enveloped, spherical, or pleomorphic viruses belonging to the large Coronaviridae family of single-stranded RNA viruses under the Nidovirales order, with crown-like spikes on the outer surface [1], causing acute or persistent infection in a wide variety of mammals and birds [2]. The coronavirus family is subdivided into four genera: $\alpha, \beta, \gamma$, and $\delta[3]$. Six human coronavirus strains have been identified so far [4], comprising $\alpha$-coronaviruses (HCoVs-NL63 and HCoVs-229E), $\beta$-coronaviruses (HCoVs-OC43 and HCoVs-HKU1), severe acute respiratory syndrome coronavirus (SARS-CoV) [5], and Middle East respiratory syndrome coronavirus (MERS-CoV) as well as SARS-CoV-2 [6]. Due to their widespread distribution, large genetic

Copyright: Islam, et al. This article is an open access article distributed under the terms of the Creative Commons Attribution 4.0 International License (http://creativecommons.org/licenses/ by/4.0/), which permits unrestricted use, distribution, and reproduction in any medium, provided you give appropriate credit to the original author(s) and the source, provide a link to the Creative Commons license, and indicate if changes were made. The Creative Commons Public Domain Dedication waiver (http:// creativecommons.org/ publicdomain/zero/1.0/) applies to the data made available in this article, unless otherwise stated. diversity, frequent genome recombination, and growing human-animal interface, new coronaviruses have been emerging in humans periodically [7].

A novel coronavirus outbreak has occurred in Wuhan, China, at the end of December 2019, epidemiologically suspected to be linked to a wet market [8] and subsequently spreading worldwide. Scientific studies have reported that the virus is related to $\beta$-coronavirus; initially, Chinese researchers have named it Wuhan coronavirus or 2019 novel coronavirus. Later, it was named SARS-CoV-2, and the disease was named coronavirus disease 2019 (COVID-19) by the International Committee on Taxonomy of Viruses $[7,9,10]$. Unlike in many countries, from vegetable, poultry, and fish to illegal wild animals, including peacock, bear, deer, pangolin, civet, turtle, and bat, everything is sold in Chinese wet markets [11]. Among them, bats can host many mammalian detrimental viruses without showing any symptoms [12]. Scientific reports suggested that there is a $96 \%$ genetic similarity between bat coronaviruses and SARSCoV-2 [13]; therefore, the bat might be a potential reservoir of SARS-CoV-2, just like SARS-CoV and MERS-CoV, where civets and dromedary camels are considered the potential intermediate hosts [14]. The 
possible origin of SARS-CoV-2 from Malayan pangolin (Manis javanica) has been reported as well [15]. However, the exact potential reservoir and intermediate host of the virus have not yet been identified. For several reasons, this pandemic is given the greatest attention by the World Health Organization (WHO) and nearly all countries worldwide. As reported by the WHO, 8093 people from 26 countries were infected with SARS-CoV with a mortality rate of $9 \%$ in 2003. Besides other coronaviruses, SARS-CoV-2 shows a fast transmissibility rate and a higher mortality rate due to comorbidity [16]. According to a WHO report, a much higher degree of transmission is observed in SARS-CoV-2, where more than 138.68 million people became infected across 223 countries, with a mortality rate $2.15 \%$ so far until the preparation of this manuscript. SARS-CoV-2 has shown a median basic case reproduction number $\left(\mathrm{R}_{0}\right)$ of 5.7 [17], which indicate its remarkable contagiousness. Altogether, the estimated $\mathrm{R}_{0}$, case morbidity, and case mortality rate of SARS-CoV-2 are noticeably higher than SARS-CoV, and the genetic recombination event observed at the $S$ protein in the receptor-binding domain (RBD) region of SARS-CoV-2 might have enhanced its transmission ability [18]. However, after phylogenetic and recombination analyses with the sarbecovirus subgenus, the novel virus demonstrated a dissimilar clustering with a SARS-like coronavirus sequence, rejecting the chance of recent recombination [19]. Full genome analysis of SARS-CoV-2 showed that it is different from SARS$\mathrm{CoV}$ and MERS-CoV, but it forms a unique lineage with the sarbecovirus [8]. It was observed previously that MERS-CoV expresses cell receptors after continuous passaging, leading to a mutation in the $\mathrm{S}$ protein gene that enhances viral entry in animal species causing cross-species transmission [20].

To reveal the cause of the unique high contagiousness, zoonotic association, and animal-to-human transmission dynamics of SARS-CoV-2, further molecular and epidemiological studies are needed. More studies might facilitate the prevention and control of the current pandemic and the preparation for future similar outbreaks. This review discusses the different coronavirus diseases along with their possible animal reservoirs and the potential intermediate host of COVID-19.

\section{Primary Reservoirs and Hosts of Coronaviruses}

Although it is challenging to ascertain the natural animal reservoir and host range of coronaviruses and determine their zoonotic potential, it has paramount importance, as the recent SARS-CoV-2 and two other near-past serious outbreaks SARS and MERS have caused thousands of deaths $[5,6,21,22]$. Studies have found zoonotic connections with all three coronaviruses, and the bat is the suspected host; however, they seem to use a range of intermediate hosts. Several novel coronavirus strains have emerged in the last two decades in animals, such as pigs, horses, monkeys, camels, and civets, with potential for zoonotic transmission. Coronavirus infections have been reported in children caused by bovine coronaviruses $[23,24]$ and laboratory animals, such as mice, rats, guinea pigs, rabbits, and poultry, manifested as respiratory infections and reproductive disorders [25]. Different gastrointestinal (GI) disorders, respiratory illnesses, and nervous symptoms have been reported in coronavirus infections in bovine, canine, feline, and swine species $[23,24,26-28]$. Initially, scientists have predicted raccoon dogs and palm civets as the key reservoirs of SARS-CoV, later viral RNA detection confirmed palm civets as the secondary host [29], although the details linking bat and farmed palm civets are unclear [30-32]. After detecting the anti-SARS antibody in Rhinolophus bats, it was considered a potential source of virus replication [33]. In 2012, MERS$\mathrm{CoV}$ belonged to the $\beta$-coronavirus in Saudi Arabia, where dromedary camels were identified as the primary host [34]. Further, the virus was detected from Pipistrellus and Perimyotis bats [35]; therefore, the bat was confirmed as the potential reservoir of MERS$\mathrm{CoV}$ infections.

\section{What is COVID-19?}

COVID-19 is a highly transmittable and pathogenic viral infection affecting mainly the respiratory system and executes symptoms closely similar to that of pneumonia [8]. Before its worldwide spread, the virus was first identified in Wuhan, China. The disease is caused by SARS-CoV-2, a virus of the family Coronaviridae [36]. Coronaviridae is a large family of RNA viruses that infect mammals (including humans) and birds. "Corona" means "crown" and they are so named because of their appearance. These viruses are responsible for diseases, such as MERS [21] and SARS. It has been found through genomic analysis that SARS-CoV-2 is phylogenetically related to SARS-like bat viruses [17]. Therefore, it is assumed with great certainty that the primary reservoir of this virus could be bats, although the intermediate source of origin and pathways of human transmission are still obscure [1]. However, it has been confirmed widely that the human-to-human transmission of the virus occurs exceptionally rapidly than any other from the family.

\section{Outbreak Scenario}

Several recent epidemics of viral respiratory infections have mostly emerged and spread worldwide from China. Several reasons behind it are speculated, including lots of livestock farming with limited sanitation and lax oversight; dense human population mixing with all sorts of domestic and exotic animals in wet markets; and huge trade due to the production of a wide range of commodities, tourism, and military transactions with most countries worldwide [37]. At the very end of 2019, an outbreak of the serious pneumonic disease in humans 
was reported in Wuhan, China. A novel coronavirus was identified from the patients [38] and named SARS$\mathrm{CoV}-2$. Soon after identifying the primary case, humanto-human transmission occurred very rapidly and spread globally within 1 month. Because of this, on January 30 , 2020 , the WHO declared a global public health emergency. It was speculated that the virus might have originated from Huanan Seafood Market in Wuhan City, Hubei Province, China, as contact tracing showed that many of the early cases had a connection to the market [36]. The identification of SARS-CoV-2 from environmental samples of the market provided further evidence of the role of this market in the emergence of this novel virus [39]. The total confirmed cases worldwide and in Bangladesh are illustrated in Figure-1.

\section{Transmission Dynamics of SARS-CoV-2}

The transmission dynamics of SARS-CoV-2 are illustrated in Figure-2 [8,13,15,36,40-43].

\section{Malayan Pangolin and SARS-CoV-2}

The role of wild animal and wet markets seems important in the emergence of SARS-CoV-2, as previous outbreaks of SARS from 2002 to 2003 involved similar types of wet markets [44]. Moreover, it was observed that a number of mammalian species were brought to the Huanan Seafood Market (predicted to be linked with the COVID-19 outbreak) before the outbreak [39], which made the basis for the speculation of zoonotic transmission. Therefore, several research studies have been conducted in different parts of the world to gather scientific evidence of the SARS-CoV-2-related virus in

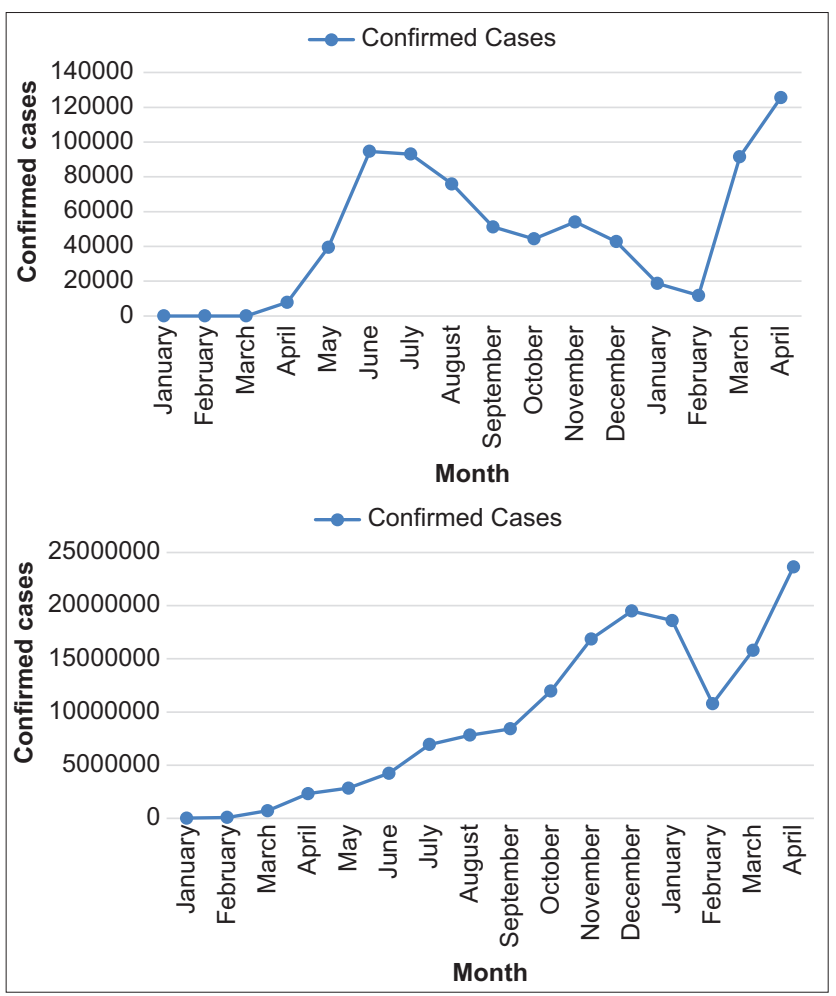

Figure-1: Monthly COVID-19 confirmed cases from January' 2020 to April' 2021 (a) World data (b) Bangladesh data. wild animals. However, a coronavirus closely related to SARS-CoV-2 was detected from a Rhinolophus affinis bat in Yunnan in 2013. Studies on pangolins smuggled into southern China succeeded in identifying the related virus [15]. Similar viruses have not yet been detected in other wildlife species.

Malayan pangolin, also named Sunda pangolin or Javan pangolin (M. javanica), is a carnivore habituated in Southeast Asia [45]. Interests grew to identify SARS-CoV-2-related viruses in pangolins due to its close contact with humans as a food source and the use of its scales in traditional Chinese medicine [46]. As the current pandemic of COVID-19 is the worst in a century, many research studies are ongoing to understand the viral evolution. A link between COVID-19 and pangolin coronavirus (pangolin-CoV) was proven in some recent studies, although evidence is not enough to prove if pangolins are the host; rather, they more certainly might be the intermediate host [15]. Recently published data showed that pangolin-CoV has approximately $85.5-92.4 \%$ genomic similarity with SARS-CoV-2 and is also closely related to bat coronavirus [47]. The study revealed structural similarity between pangolin-CoV and human coronavirus that allowed the transmission into human cells and proposed an exceptional bat-to-pangolin-to-human transmission [48]. Although the coronavirus was detected years ago as a potential human pathogen as well as a respiratory and GI tract infectious agent in domestic and wild animals (cattle, buffalo, rabbit, camel, dog, cat, civet, rat, mouse, bat, etc.), its genetic diversity and zoonotic transmission are yet to be proven with enough certainty [2].

\section{Viral Sequence Analysis from Malayan Pangolin}

The previous findings have suggested that $\beta$-coronavirus might naturally live in pangolin and potentially can infect humans. The pangolin is also one of the major suspects for the zoonotic transmission of the ongoing COVID-19 outbreak [49]. However, the pathogenesis of this pangolin-CoV remains to be studied. Recent molecular-level investigations have shown that pangolin-CoV is $91 \%$ and $90 \%$ related to the novel SARS-CoV-2 (causing COVID-19) and bat coronavirus, respectively [50]. Another recent study has suggested about $85-92 \%$ genetic similarity of pangolin-CoV and SARS-CoV-2, where pangolin-associated coronaviruses belong to two sublineages of SARS-CoV-2-related coronaviruses [15]. These findings showed an identical cleavage site in the spike protein (S protein) between the viruses [51]. The S protein of coronaviruses binds to host receptors through RBDs and plays an essential role in initiating virus infection and determining host tropism [4]. A previous study has suggested that SARS-CoV-2, SARS-CoV, and Bat-CoV-RaTG13 have similar RBDs, suggesting that they use the same receptor angiotensin-converting enzyme II (ACE2) [51]. Scientific analysis showed that pangolin-CoV-2020 had a much conserved 
TRANSMISSION DYNAMICS OF

SARS-COV-2

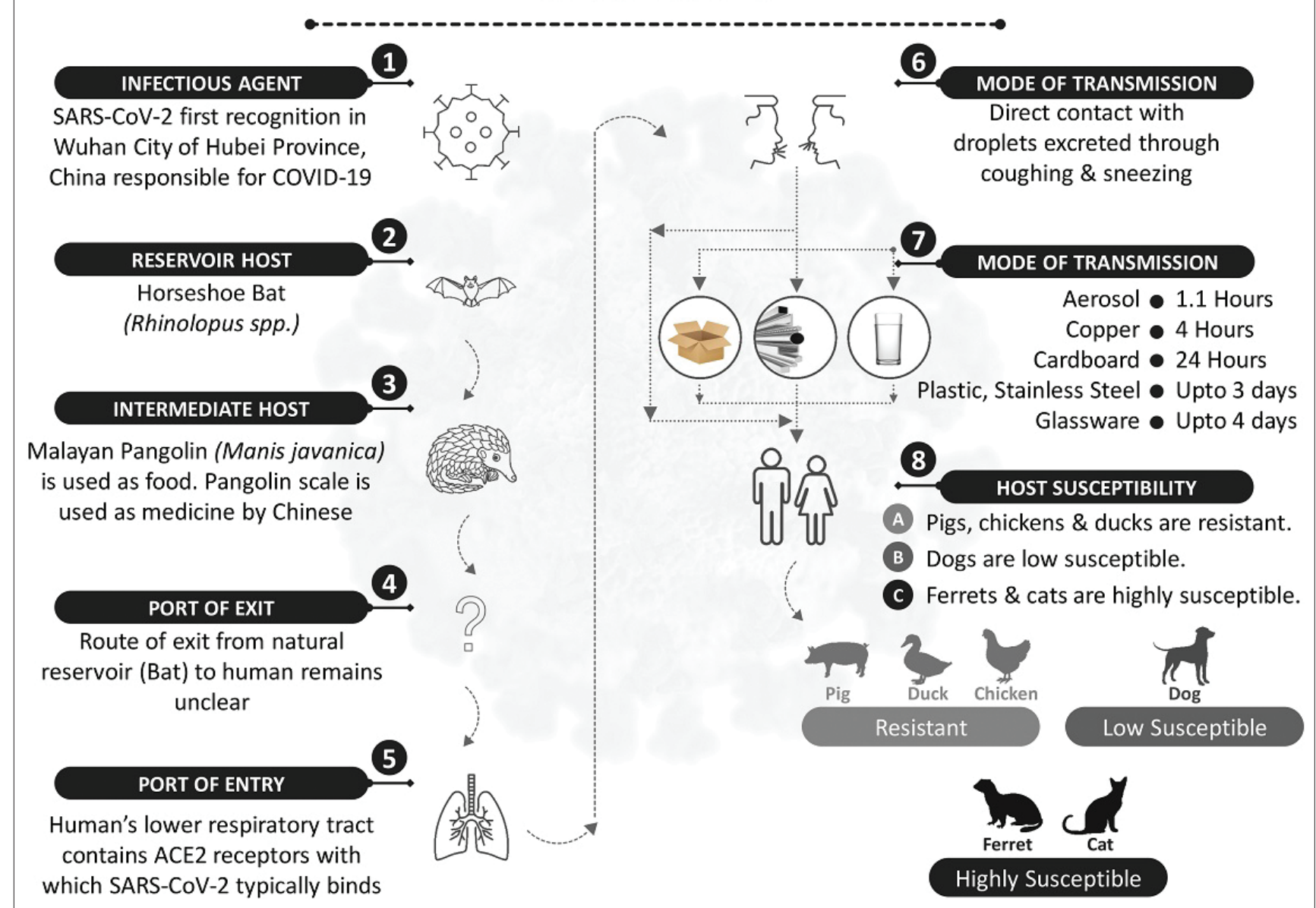

Figure-2: Transmission dynamics of SARS-Cov-2; source modifiers: (1) [41], (2) [13], (3) [15], (4) [40], (5) [8], (6) $[36],(7)[42],(8)[43]$.

RBD to these three viruses rather than MERS-CoV, suggesting that pangolin-CoV is very likely to use ACE2 as its receptor. In contrast, the ACE2 receptor is present in pangolins with high sequence conservation with those in the gene homolog in humans. However, these findings do not prove a zoonotic link of pangolin-CoV-2020.

By reviewing the available genetic data, it can be concluded that the determination of several lineages of pangolin-CoV and their similarity with SARSCoV-2 might indicate that pangolin could be a potential intermediate host of the human novel virus with an unknown potential to infect humans. Results from different studies did not discard the chance of having other coronaviruses in pangolins. Moreover, available data do not support with certainty that SARS-CoV-2 emerged directly from pangolin-CoV. Thus, extended surveillance of coronaviruses in pangolins is necessary to improve the understanding of the range of coronaviruses in pangolins. Although the transmission link between pangolins and humans is not yet clear from published data, preventive actions such as wildlife conservation and limiting human exposure to wildlife could effectively reduce the spillover risks of coronaviruses from wild animals to humans.

\section{Evolutionary Perspectives}

The evolutionary history was inferred using the neighbor-joining method. The optimal tree with the sum of branch length of 2.98423808 is shown. The evolutionary distances were computed using the maximum composite likelihood method and are in the units of the number of base substitutions per site. The proportion of sites where at least an unambiguous base is present in at least one sequence for each descendent clade is shown next to each internal node in the tree. The analysis involved 26 nucleotide sequences (Table-1). All positions containing gaps and missing data were eliminated. There were a total of 21,197 positions in the final dataset. Evolutionary analyses were conducted in MEGA7 and are illustrated in Figure-3.

\section{Bats and SARS-CoV-2}

Bats are the natural host of many coronaviruses and may cause diseases in many other animals through evolution [7,40]. It is hypothesized that most human coronaviruses might have emerged from the bat reservoir [30,71]. Based on the assumption after the COVID-19 pandemic, interest 
Table-1: Comparison between SARS-CoV and SARS-CoV-2.

\begin{tabular}{|c|c|c|c|}
\hline Features & SARS-CoV & SARS-CoV-2 & References \\
\hline Emergence date & November-2002 & December-2019 & {$[76-79]$} \\
\hline Area of emergence & Guangdong, China & Wuhan, China & \\
\hline Date of fully controlled & July-2003 & Not controlled yet & \\
\hline Key hosts & Bat, palm civets, and Raccon dogs & Bat and Malayan pangolin & {$[15,36,80,81]$} \\
\hline Number of countries infected & 26 & 220 & [82] \\
\hline Entry receptor in humans & ACE2 receptor & ACE2 receptor & {$[36,83,84]$} \\
\hline Sign and symptoms & $\begin{array}{l}\text { Fever, malaise, myalgia, headache, } \\
\text { diarrhea, shivering, cough, and } \\
\text { shortness of breath }\end{array}$ & Cough, fever, and shortness of breath & {$[84-86]$} \\
\hline Disease caused & SARS, ARDS & SARS, COVID-19 & {$[41,87]$} \\
\hline Total infected patients & 8,098 & 66422058 (till December 7, 2020) & {$[1,88]$} \\
\hline Total died patients & $776(9.6 \%$ mortality rate $)$ & $\begin{array}{l}1532418(2.31 \% \text { mortality rate) (till } \\
\text { December } 7,2020)\end{array}$ & {$[82]$} \\
\hline
\end{tabular}

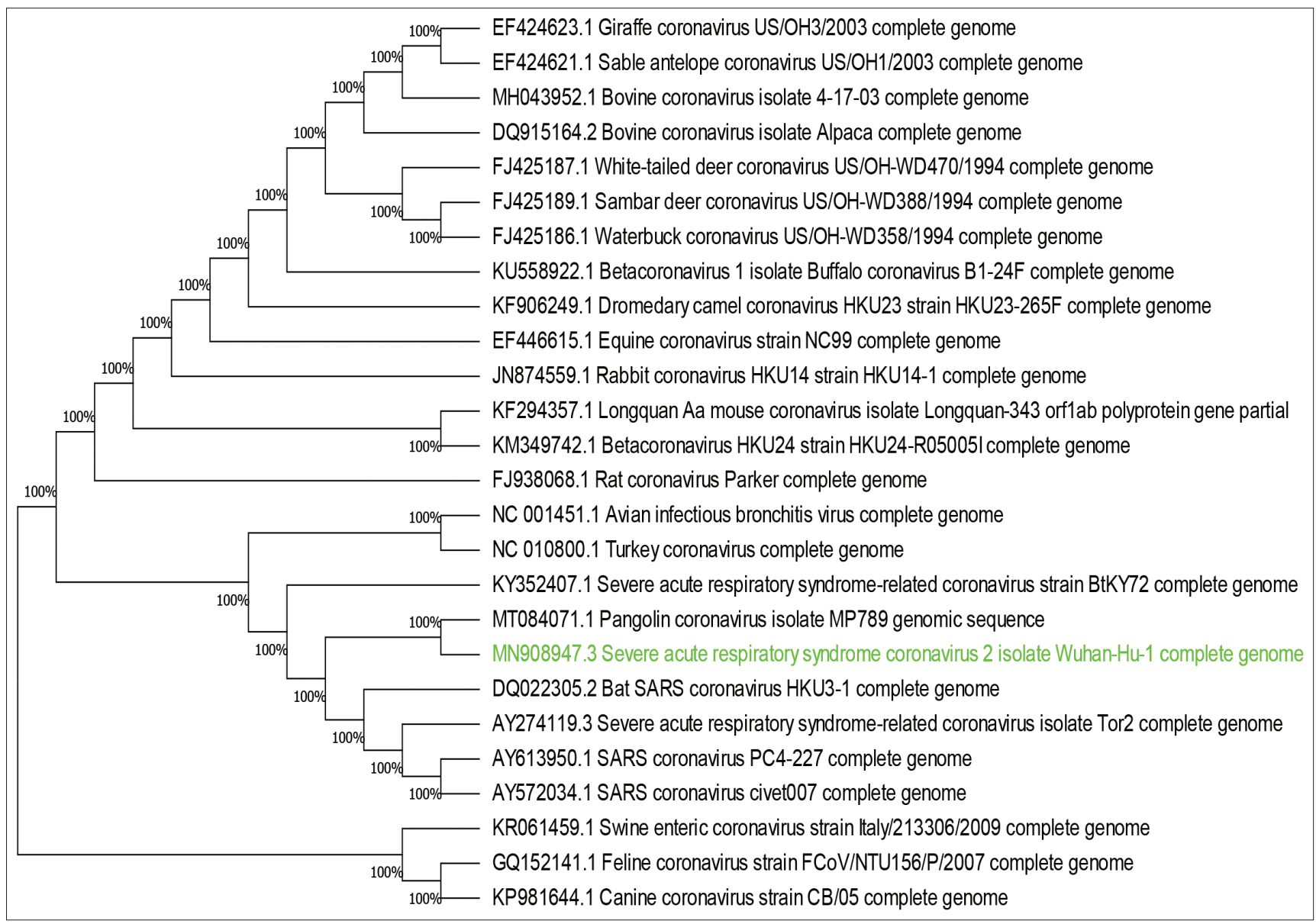

Figure-3: Evolutionary relationships of taxa.

grew among several researchers to determine the genetic connection between SARS-CoV-2 and bat coronaviruses and was successfully confirmed by several studies $[4,19,72,73]$. SARS-related coronavirus (RaTG13) showed 96.2\% similarity with SARS-CoV-2 [19] but was not very closely linked to the genomes of SARS-CoV $(\sim 79 \%)$ or MERSCoV ( $\sim 50 \%)$ [74]. Further, the ACE2 receptor was used by both SARS-CoV and SARS-CoV-2 [51]. Although the overall genomic nucleotides differ by $\sim 4 \%$ between SARS-CoV-2 and Bat-CoV-RaTG13, the genomic average $\mathrm{dS}$ was 0.17 , which means that the divergence at the neutral sites is $17 \%$ between these two viruses [75]. SARS-CoV-2 is classified as a novel $\beta$-coronavirus belonging to the sarbecovirus subgenus of the Coronaviridae family. The genome sequence of SARS-CoV-2 is about $89 \%$ identical to bat SARS-like CoVZXC21 and $82 \%$ identical to human SARS-CoV [41]. It has been reported that SARS-CoV-2 uses the same cell entry receptor (ACE2) to infect humans, as SARS-CoV [13], so a clinical similarity between the two viruses could be expected.

\section{Comparison between SARS-CoV and SARS-CoV-2}

The key features comparing the viruses are shown in Table-1 [1,15,36,41,77-88]. 
Table-1: GenBank accession numbers of coronavirus sequences used in this study.

\begin{tabular}{|c|c|c|c|c|}
\hline SL & Accession no. & Organism & Location & References \\
\hline 01 & MN908947 & Severe acute respiratory syndrome coronavirus 2 & China & {$[38]$} \\
\hline 02 & FJ425187 & White-tailed deer coronavirus US/OH-WD470/1994 & USA & [52] \\
\hline 03 & FJ425186 & Waterbuck coronavirus US/OH-WD358/1994 & USA & [52] \\
\hline 04 & NC_010800 & Turkey coronavirus & Canada & [53] \\
\hline 05 & GQ152141 & Feline coronavirus & Taiwan & [54] \\
\hline 06 & EF424623 & Giraffe coronavirus US/OH3/2003 & USA & [55] \\
\hline 07 & KF294357 & Longquan Aa mouse coronavirus & China & [56] \\
\hline 08 & MT084071 & Pangolin coronavirus & China & [57] \\
\hline 09 & JN874559.1 & Rabbit coronavirus HKU14 & China & [58] \\
\hline 10 & FJ938068 & Rat coronavirus Parker & USA & [59] \\
\hline 11 & FJ425189 & Sambar deer coronavirus US/OH-WD388/1994 & USA & [54] \\
\hline 12 & AY274119.3 & Severe acute respiratory syndrome-related coronavirus & Canada & {$[60]$} \\
\hline 13 & KY352407.1 & Severe acute respiratory syndrome-related coronavirus & Kenya & [61] \\
\hline 14 & AY613950.1 & SARS coronavirus PC4-227 & China & {$[62]$} \\
\hline 15 & KR061459.1 & Swine enteric coronavirus & Italy & [63] \\
\hline 16 & EF446615.1 & Equine coronavirus & USA & [64] \\
\hline 17 & AY572034.1 & Civet SARS CoV 007/2004 & China & [44] \\
\hline 18 & KM349742.1 & China Rattus coronavirus HKU24 & China & [58] \\
\hline 19 & KP981644.1 & Canine coronavirus & Italy & [65] \\
\hline 20 & KU558922.1 & Buffalo coronavirus B1-24F & Bangladesh & [66] \\
\hline 21 & МH043952.1 & Bovine coronavirus & USA & [67] \\
\hline 22 & DQ022305.2 & Bat SARS coronavirus HKU3-1 & China & [58] \\
\hline 23 & NC_001451.1 & Infectious bronchitis virus & Canada & [68] \\
\hline 24 & EF424621.1 & Sable antelope coronavirus US/OH1/2003 & USA & [64] \\
\hline 25 & DQ915164.2 & Bovine coronavirus isolate Alpaca & USA & [69] \\
\hline 26 & KF906249.1 & Dromedary camel coronavirus HKU23 & UAE & [70] \\
\hline
\end{tabular}

\section{Are there Other Animal Reservoirs of SARS-CoV-2?}

The transmission of pathogens from animals to humans and vice versa is called zoonotic spillovers [88], which are speculated to be responsible for about $70-75 \%$ of the emerging epidemics in recent decades [89]. Wild animals, especially bats, are widely suspected as a reservoir host of many viruses and might play an important role in transmitting etiological agents of Nipah, Hendra, Ebola, SARS, MERS, 229E, NL63, and recently COVID-19 [7,90]. Domestic animals are suspected as intermediate and amplifying hosts of coronaviruses, where the ancestor of HCoVs-OC43 was found in domestic cattle and swine, and this host switching caused the pandemic of human respiratory diseases in 1890 [91]. Some scientists have indicated snakes as the possible reservoir and intermediate host of SARS-CoV-2 [92]. Further, the turtle (Chrysemys picta bellii, Chelonia mydas, and Pelodiscus sinensis) was speculated as a potential intermediate host of SARS-CoV-2 besides snake and pangolin based on the interaction between the key amino acid of the S protein in RBD and ACE2 [47]. It is still obscure which animal species served as the intermediate host, but some scientists indicated that two potential hosts of SARS-CoV-2 might be bats $(R$. affinis) and mink, where mink are considered intermediate host [93].

\section{Role of Wildlife in COVID-19}

Wildlife is extensively responsible for zoonotic epidemics, including $75 \%$ of the emerging infectious human diseases [94]. From 2000 to 2013, 25 emerging or reemerging infectious diseases were identified as great perils for mankind, closely linked to wildlife [95]. Human infections with SARS-CoV, HIV, Nipah virus, and H5N1 influenza originated clearly from wildlife [96]. As the pandemic feature of SARS-CoV-2 shares common attributes with major outbreaks in recent years, such as SARS-CoV, avian influenza, MERS, and Ebola, the origin and spread of these viruses are often thought to be intimately linked to wildlife. The risk of zoonotic disease transmission is largely exacerbated by the breach of barrier between humans and wildlife [97]. Change in the ecosystem elevates the epidemiological interactions between wildlife and livestock, contributing to the zoonotic transfer [97]. Loss of wildlife biodiversity affects the correlation between the host and the vector, accelerating the spread of infectious diseases [98]. Wildlife habitat destruction leads to expanded wildlife trade [99]. According to Beirne [100], wildlife trade is one of the preponderant risk factors causing pathogen spillover. Furthermore, for COVID-19, there is a suspicion that SARS-CoV-2 is interlinked with intermediate animal host, as the initial COVID19 cases were identified from a wet market in Wuhan where wild animals are bought and sold [101]. Wet markets massively promote wildlife trade, and this practice has led to the mushrooming of zoonotic diseases among the animals and to purchasers at markets [102].

SARS-CoV-2 has been isolated from a wide range of animal species and captive wildlife in close contact with human COVID-19 cases. This virus has 
also been shown to infect wild species under experimental conditions. At present, coronavirus has been found in cattle, horses, ferrets, bats, dogs, and others [103]. The evidence of SARS-CoV-2-positive confirmation with respiratory symptoms in several tigers in Bronx Zoo (New York City, United States) indicates the occasional spillover from humans to domestic or captive animals [104]. Other than New York City, COVID-19-positive Malayan tigers were enlisted in a zoo in Tennessee, where the caretaker was also SARS-CoV-2-infected [105]. Furthermore, minks on two farms in the Netherlands were reported with SARS-CoV-2 infection associated with clinical signs and pathological and virological findings [106]. In addition, the virus has also been exhibited to infect an immense number of wild species under experimental conditions, such as rhesus and cynomolgus macaques, ferrets, cats, and golden Syrian hamsters [107-111].

In contrast, wildlife is being implicitly blamed for the pandemic, but researchers relentlessly try to find a way out of this catastrophic disaster. For example, ACE2 receptors in cats and ferrets are close to human ACE2 [112]. ACE2 receptors of rhesus macaques, Syrian hamsters, and common marmosets have been reported to be profoundly similar to that of humans; among them, hamster ACE2 showed the maximum binding affinity to both SARS-CoV-2 and SARS-CoV spike proteins, indicating an effective animal model for vaccines and drugs against SARS-CoV-2 [112].

\section{Conclusion and Perspectives}

COVID-19, a devastating respiratory disease, is evolving as a potential threat to mankind, challenging science and technology. Zoonotic transmission has become the burning question because this new virus is analogous to the same family of viruses as SARS-CoV linked with civets and MERS-CoV connected with dromedary camels. Furthermore, the SARS-CoV-2 genomic sequence in humans and pangolins is noteworthy. These animals are suspected to be the reservoir for this infection. Because findings have suggested that this disease might be from any wild animals, there is a need for more extensive research on exotic animals, environmental change, pollution, wildlife conservation, food habit, and others to ascertain the role of the animals in the spread of the virus. This study reviewed the transmission potential of SARS-CoV-2 cases identified in different wild and domestic animals. Although there is no independent corroboration that humans can transmit COVID-19 to their pets or other animals, it is recommended to follow preventive measures. However, to ameliorate the pandemic, constructive public health strategies, regular monitoring and surveillance, efficacious medication, and a mass vaccination program are needed. In addition, the ecofriendly Wild Animal Conservation Law executing the concept of One Health is anticipated to make an extensive and systematic revision to control the wildlife trade and breach the zoonotic transmission chain.

\section{Authors' Contributions}

MSI: Conceptualization, data curation, formal analysis, and drafted and edited the manuscript. FMYH: Conceptualization, phylogenetic analysis and drafted the manuscript. CN: Formal analysis visualization, and drafted and revised the manuscript. JA: Data curation, formal analysis, and reviewed and edited the manuscript. MSN: Data curation and visualization. MAF: Data curation and reviewed and edited the manuscript. SC: Supervision, validation, and reviewed and edited the manuscript. All authors read and approved the final manuscript.

\section{Acknowledgments}

The authors expressed their gratitude to Department of Pathology and Parasitology, Chattogram Veterinary and Animal Sciences University (CVASU), Bangladesh and One Health Institute, CVASU, Bangladesh, for financial support.

\section{Competing Interests}

The authors declare that they have no competing interests.

\section{Publisher's Note}

Veterinary World (Publisher of International Journal of One Health) remains neutral with regard to jurisdictional claims in published institutional affiliation.

\section{References}

1. Shereen, M.A., Khan, S., Kazmi, A., Bashir, N., Siddique, R., Adnan, M., Khan, S., Kazmi, A., Bashir, N. and Siddique, R. (2020) COVID-19 infection: Origin, transmission, and characteristics of human coronaviruses. J. $A d v$. Res., 24: 91-98.

2. Weiss, S.R. and Navas-Martin, S. (2005) Coronavirus pathogenesis and the emerging pathogen severe acute respiratory syndrome coronavirus. Microbiol. Mol. Biol. Rev., 69(4): 635-664.

3. Yang, D. and Leibowitz, J.L. (2015) The structure and functions of coronavirus genomic 3' and 5' ends. Virus Res., 206: 120-133.

4. Wu, A., Peng, Y., Huang, B., Ding, X., Wang, X., Niu, P., Meng, J., Zhu, Z., Zhang, Z., Wang, J., Sheng, J., Quan, L., Xia, Z., Tan, W., Cheng, G. and Jiang, T. (2020) Genome composition and divergence of the novel coronavirus (2019-nCoV) originating in China. Cell Host Microbe, 27(3): 325-328.

5. Drosten, C., Günther, S., Preiser, W., Van Der Werf, S., Brodt, H.R., Becker, S., Rabenau, H., Panning, M., Kolesnikova, L., Fouchier, R.A. and Berger, A. (2003) Identification of a novel coronavirus in patients with severe acute respiratory syndrome. N. Engl. J. Med., 348(20): 1967-1976.

6. Zaki, A.M., Van Boheemen, S., Bestebroer, T.M., Osterhaus, A.D.M. and Fouchier, R.A.M. (2012) Isolation of a novel coronavirus from a man with pneumonia in Saudi Arabia. N. Engl. J. Med., 367(19): 1814-1820.

7. Cui, J., Li, F. and Shi, Z.L. (2019) Origin and evolution of pathogenic coronaviruses. Nat. Rev. Microbiol., 17(3): 181-192.

8. Zhu, N., Zhang, D., Wang, W., Li, X., Yang, B., Song, J., Zhao, X., Huang, B., Shi, W., Lu, R., Niu, P., Zhan, F., Ma, X., Wang, D., Xu, W., Wu, G., Gao, G.F. and Tan, W. 
(2020) A novel coronavirus from patients with pneumonia in China, 2019. N. Engl. J. Med., 382(8): 727-733.

9. Lai, C.C., Shih, T.P., Ko, W.C., Tang, H.J. and Hsueh, P.R. (2020) Severe acute respiratory syndrome coronavirus 2 (SARS-CoV-2) and coronavirus disease-2019 (COVID-19): The epidemic and the challenges. Int. J. Antimicrob. Agents, 55(3): 105924.

10. World Health Organization. (2020a) Situation Reports. Laboratory Testing for Coronavirus Disease 2019 (COVID-19) in Suspected Human Cases: Interim Guidance, 2 March 2020. World Health Organization, Geneva.

11. Minhas, S. (2020) Could India be the origin of next COVID19 like epidemic? Sci. Total Environ., 728: 138918.

12. Daszak, P., Olival, K. and Li, H. (2020) A strategy to prevent future epidemics similar to the 2019-nCoV outbreak. Biosaf. Health, 2(1): 6-8.

13. Zhou, P., Yang, X.L., Wang, X.G., Hu, B., Zhang, L., Zhang, W., Si, H.R., Zhu, Y., Li, B., Huang,C.L., Chen, H.D., Chen, J., Luo, Y., Guo, H., Jiang, R.D., Liu, M.Q., Chen, Y., Shen, X.R.,Wang, X., Zheng, X.S., Zhao, K., Chen, Q.J., Deng, F., Liu, L.L., Yan, B., Zhan, F.X.,Wang, Y.Y., Xiao, G.F. and Shi, Z.L. (2020) A pneumonia outbreak associated with a new coronavirus of probable bat origin. Nature, 579(7798): 270-273.

14. Park, M., Thwaites, R.S. and Openshaw, P.J.M. (2020) COVID-19: Lessons from SARS and MERS. Eur. J. Immunol., 50(3): 308-311.

15. Lam, T.T.Y., Shum, M.H.H., Zhu, H.C., Tong, Y.G., Ni, X.B., Liao, Y., Wei, W., Cheung, W.Y., Li, W.J., Li, L., Leung, G.M., Holmes, E.C., Hu, Y. and Guan, Y. (2020) Identifying SARS-CoV-2 related coronaviruses in Malayan pangolins. Nature, 583(7815): 282-285.

16. Rana, E.A., Chowdhury, N.S., Islam, M.S., Ara, J., Nasrin, S.S., Dutta, P., Bristi, S.Z.T., Nizami, T.A., Chakraborty, P. and Siddiki, A.Z. (2020) Molecular detection and prevalence of SARS-CoV-2 during the early outbreak in Southern Bangladesh. Int. J. One Health, 6(2): 153-159.

17. Sanche, S., Lin, Y.T., Xu, C., Romero-Severson, E., Hengartner, N. and Ke, R. (2020) High contagiousness and rapid spread of severe acute respiratory syndrome coronavirus 2. Emerg. Infect. Dis., 26(7): 1470-1477.

18. Belouzard, S., Millet, J.K., Licitra, B.N. and Whittaker, G.R. (2012) Mechanisms of coronavirus cell entry mediated by the viral spike protein. Viruses, 4(6): 1011-1033.

19. Paraskevis, D., Kostaki, E.G., Magiorkinis, G., Panayiotakopoulos, G., Sourvinos, G. and Tsiodras, S. (2020) Full-genome evolutionary analysis of the novel coronavirus (2019-nCoV) rejects the hypothesis of emergence as a result of a recent recombination event. Infect. Genet. Evol., 79: 104212.

20. Letko, M., Miazgowicz, K., McMinn, R., Seifert, S. N., Sola, I., Enjuanes, L., Carmody, A., van Doremalen, N. and Munster, V. (2018) Adaptive evolution of MERS-CoV to species variation in DPP4. Cell Rep., 24(7): 1730-1737.

21. Cunha, C.B. and Opal, S.M. (2014) Middle East respiratory syndrome (MERS) a new zoonotic viral pneumonia. Virulence, 5(6): 650-654.

22. World Health Organization. (2003) Consensus Document on the Epidemiology of Severe Acute Respiratory Syndrome (SARS). World Health Organization, Geneva.

23. Suzuki, T., Otake, Y., Uchimoto, S., Hasebe, A. and Goto, Y. (2020) Genomic characterization and phylogenetic classification of bovine coronaviruses through whole genome sequence analysis. Viruses, 12(2): 183.

24. Zhang, X.M., Herbst, W., Kousoulas, K.G. and Storz, J. (1994) Biological and genetic characterization of a hemagglutinating coronavirus isolated from a diarrhoeic child. $J$. Med. Virol., 44(2): 152-161.

25. Dhama, K., Singh, S.D., Barathidas, R., Desingu, P.A., Chakrabort, S., Tiwari, R. and Kumar, M.A. (2014) Emergence of avian infectious bronchitis virus and its variants need better diagnosis, prevention and control strategies: A global perspective. Pak. J. Biol. Sci., 17(6): 751-767.

26. Erles, K. and Brownlie, J. (2008) Canine respiratory coronavirus: An emerging pathogen in the canine infectious respiratory disease complex. Vet. Clin. North Am. Small Anim. Pract., 38(4): 815-825.

27. Licitra, B., Duhamel, G. and Whittaker, G. (2014) Canine enteric coronaviruses: Emerging viral pathogens with distinct recombinant spike proteins. Viruses, 6(8): 3363-3376.

28. Tekes, G. and Thiel, H.J. (2016) Feline coronaviruses. $A d v$. Virus Res., 96: 193-218.

29. Kan, B., Wang, M., Jing, H., Xu, H., Jiang, X., Yan, M., Liang, W., Zheng, H., Wan, K., Liu, Q. and Cui, B. (2005) Molecular evolution analysis and geographic investigation of severe acute respiratory syndrome coronavirus-like virus in palm civets at an animal market and on farms. J. Virol, 79(18): 11892-11900.

30. Li, W., Shi, Z., Yu, M., Ren, W., Smith, C., Epstein, J. H., Wang, H., Crameri, G., Hu, Z., Zhang, H., Zhang, J., McEachern, J., Field, H., Daszak, P., Eaton, B.T., Zhang, S. and Wang, L.F. (2005) Bats are natural reservoirs of SARSlike coronaviruses. Science, 310(5748): 676-679.

31. Wang, L.F. and Eaton, B.T. (2007) Bats, civets and the emergence of SARS. Curr. Top. Microbiol. Immunol., 315: 325-344.

32. Wang, L.F., Shi, Z., Zhang, S., Field, H., Daszak, P. and Eaton, B. (2006) Review of bats and SARS. Emerg. Infect. Dis., 12(12): 1834-1840.

33. Shi, Z. and Hu, Z. (2008) A review of studies on animal reservoirs of the SARS coronavirus. Virus Res., 133(1): 74-87.

34. Paden, C.R., Yusof, M.F.B., Al Hammadi, Z.M., Queen, K., Tao, Y., Eltahir, Y.M., Elsayed, E.A., Marzoug, B.A., Bensalah, O.K.A., Khalafalla, A.I. and Al Mulla, M. (2018) Zoonotic origin and transmission of Middle East respiratory syndrome coronavirus in the UAE. Zoonoses Public Health, 65(3): 322-333.

35. Annan, A., Baldwin, H.J., Corman, V.M., Klose, S.M., Owusu, M., Nkrumah, E.E., Badu, E.K., Anti, P., Agbenyega, O., Meyer, B. and Oppong, S. (2013) Human betacoronavirus 2c EMC/2012-related viruses in bats, Ghana and Europe. Emerg. Infect. Dis., 19(3): 456.

36. Lu, R., Zhao, X., Li, J., Niu, P., Yang, B., Wu, H., Wang, W., Song, H., Huang, B., Zhu, N. and Bi, Y. (2020) Genomic characterisation and epidemiology of 2019 novel coronavirus: Implications for virus origins and receptor binding. Lancet, 395(10224): 565-574.

37. Kolifarhood, G., Aghaali, M., Saadati, H.M., Taherpour, N., Rahimi, S., Izadi, N. and Nazari, S.S.H. (2020) Epidemiological and clinical aspects of COVID-19; a narrative review. Arch. Acad. Emerg. Med., 8(1): e41.

38. Wu, F., Zhao, S., Yu, B., Chen, Y.M., Wang, W., Song, Z.G., Hu, Y., Tao, Z.W., Tian, J.H., Pei, Y.Y., Yuan, M.L., Zhang, Y.L., Dai, F.H., Liu, Y., Wang, Q.M., Zheng, J.J., Xu, L., Holmes, E.C. and Zhang, Y.Z. (2020) A new coronavirus associated with human respiratory disease in China. Nature, 579(7798): 265-269.

39. Cohen, J. (2020) Mining coronavirus genomes for clues to the outbreak's origins. Science, 31: 31.

40. Li, X., Song, Y., Wong, G. and Cui, J. (2020) Bat origin of a new human coronavirus: There and back again. Sci. China Life Sci., 63(3): 461-462.

41. Chan, J.F.W., Yuan, S., Kok, K.H., To, K.K.W., Chu, H., Yang, J., Xing, F., Liu, J., Yip, C.C.Y., Poon, R.W.S. and Tsoi, H.W. (2020) A familial cluster of pneumonia associated with the 2019 novel coronavirus indicating person-to-person transmission: A study of a family cluster. Lancet, 395(10223): 514-523.

42. Van Doremalen, N., Bushmaker, T., Morris, D.H., Holbrook, M.G., Gamble, A., Williamson, B.N., Tamin, A., Harcourt, J.L., Thornburg, N.J., Gerber, S.I. and LloydSmith, J.O. (2020) Aerosol and surface stability of 
SARS-CoV-2 as compared with SARS-CoV-1. N. Engl. J. Med., 382(16): 1564-1567.

43. Shi, J., Wen, Z., Zhong, G., Yang, H., Wang, C., Huang, B., Liu, R., He, X., Shuai, L., Sun, Z. and Zhao, Y. (2020) Susceptibility of ferrets, cats, dogs, and other domesticated animals to SARS-coronavirus 2. Science, 368(6494): 1016-1020.

44. Wang, M., Yan, M., Xu, H., Liang, W., Kan, B., Zheng, B., Chen, H., Zheng, H., Xu, Y., Zhang, E. and Wang, H. (2005) SARS-CoV infection in a restaurant from palm civet Emerg. Infect. Dis., 11(12): 1860.

45. Chong, J.L., Panjang, E., Willcox, D., Nash, H.C., Semiadi, G., Sodsai, W., Lim, N.T., Fletcher, L., Kurniawan, A. and Cheema, S. (2020) Sunda Pangolin Manis javanica (Desmarest, 1822). Pangolins. p89-108.

46. Enserink, M. (2003) Clues to the animal origins of SARS. (infectious diseases). Science, 300(5624): 1351-1352.

47. Liu, P., Jiang, J.Z., Wan, X.F., Hua, Y., Li, L., Zhou, J., Wang, X., Hou, F., Chen, J., Zou, J. and Chen, J. (2020) Are pangolins the intermediate host of the 2019 novel coronavirus (SARS-CoV-2)? PLoS Pathog., 16(5): e1008421.

48. Xiao, K., Zhai, J., Feng, Y., Zhou, N., Zhang, X., Zou, J.J., Li, N., Guo, Y., Li, X., Shen, X. and Zhang, Z. (2020) Isolation of SARS-CoV-2-related coronavirus from Malayan pangolins. Nature, 583(7815): 286-289.

49. Liu, P., Chen, W. and Chen, J.P. (2019) Viral metagenomics revealed sendai virus and coronavirus infection of Malayan pangolins (Manis javanica). Viruses, 11(11): 979.

50. Zhang, T., Wu, Q. and Zhang, Z. (2020) Probable pangolin origin of SARS-CoV-2 associated with the COVID-19 outbreak. Curr. Biol., 30(7): 1346-1351.e2.

51. Wan, Y., Shang, J., Graham, R., Baric, R.S. and Li, F. (2020) Receptor recognition by the novel coronavirus from Wuhan: An analysis based on decade-long structural studies of SARS coronavirus. J. Virol., 94(7): 1-9.

52. Alekseev, K.P., Vlasova, A.N., Jung, K., Hasoksuz, M., Zhang, X., Halpin, R., Wang, S., Ghedin, E., Spiro, D. and Saif, L.J. (2008) Bovine-like coronaviruses isolated from four species of captive wild ruminants are homologous to bovine coronaviruses, based on complete genomic sequences. J. Virol., 82(24): 12422-12431.

53. Gomaa, M.H., Barta, J.R., Ojkic, D. and Yoo, D. (2008) Complete genomic sequence of turkey coronavirus. Virus Res., 135(2): 237-246.

54. Hsieh, L.E., Lin, C.N., Su, B.L., Jan, T.R., Chen, C.M., Wang, C.H., Lin, D.S., Lin, C.T. and Chueh, L.L. (2010) Synergistic antiviral effect of Galanthus nivalis agglutinin and nelfinavir against feline coronavirus. Antiviral Res., 88(1): 25-30.

55. Hasoksuz, M., Alekseev, K., Vlasova, A., Zhang, X., Spiro, D., Halpin, R., Wang, S., Ghedin, E. and Saif, L.J. (2007) Biologic, antigenic, and full-length genomic characterization of a bovine-like coronavirus isolated from a giraffe. J. Virol., 81(10): 4981-4990.

56. Wang, W., Lin, X.D., Guo, W.P., Zhou, R.H., Wang, M.R., Wang, C.Q., Ge, S., Mei, S.H., Li, M.H., Shi, M., Holmes, E.C. and Zhang, Y.Z. (2015) Discovery, diversity and evolution of novel coronaviruses sampled from rodents in China. Virology, 474: 19-27.

57. Jiang, J.Z., Liu, P. and Chen, J.P. (2020) Pangolin Coronavirus Isolate MP789 Genomic Sequence Nucleotide. NCBI,USA.

58. Lau, Susanna K.P., Woo, P.C.Y., Li, K.S.M., Tsang, A.K.L., Fan, R.Y.Y., Luk, H.K.H., Cai, J.P., Chan, K.H., Zheng, B.J., Wang, M. and Yuen, K.Y. (2015) Discovery of a novel coronavirus, China rattus coronavirus HKU24, from Norway rats supports the murine origin of betacoronavirus 1 and has implications for the ancestor of betacoronavirus lineage A. J. Virol., 89(6): 3076-3092.

59. Spiro, D., Halpin, R., Wang, S., Hostetler, J., Overton, L., Tsitrin, T., Katzel, D., Sarmiento, M., Sitz, J., Amedeo, P., Caler, E., Lorenzi, H., Schobel, S., Sundaram, J. and
Weiss, S. (2009) Rat Coronavirus Parker, Complete Genome Nucleotide. NCBI, USA.

60. He, R., Dobie, F., Ballantine, M., Leeson, A., Li, Y., Bastien, N., Cutts, T., Andonov, A., Cao, J., Booth, T. F., Plummer, F. A., Tyler, S., Baker, L. and Li, X. (2004) Analysis of multimerization of the SARS coronavirus nucleocapsid protein. Biochem. Biophys. Res. Commun., 316(2): 476-483.

61. Tao, Y. and Tong, S. (2019) Complete genome sequence of a severe acute respiratory syndrome-related coronavirus from Kenyan bats. Microbiol. Resour. Announc., 8(28): 1-5.

62. Song, H.D., Tu, C.C., Zhang, G.W., Wang, S.Y., Zheng, K., Lei, L.C., Chen, Q.X., Gao, Y.W., Zhou, H.Q., Xiang, H. and Zheng, H.J. (2005) Cross-host evolution of severe acute respiratory syndrome coronavirus in palm civet and human. Proc. Natl. Acad. Sci., 102(7): 2430-2435.

63. Boniotti, M.B., Papetti, A., Lavazza, A., Alborali, G., Sozzi, E., Chiapponi, C., Faccini, S., Bonilauri, P., Cordioli, P. and Marthaler, D. (2016) Porcine epidemic diarrhea virus and discovery of a recombinant swine enteric coronavirus, Italy. Emerg. Infect. Dis., 22(1): 83-87.

64. Zhang, J., Guy, J.S., Snijder, E.J., Denniston, D.A., Timoney, P.J. and Balasuriya, U.B.R. (2007) Genomic characterization of equine coronavirus. Virology, 369(1): 92-104.

65. Decaro, N., Mari, V., Dowgier, G., Elia, G., Lanave, G., Colaianni, M.L. and Buonavoglia, C. (2015) Full-genome sequence of pantropic canine coronavirus. Genome Announc., 3(3): e00401-15.

66. Lau, S.K.P., Tsang, A.K.L., Ahmed, S.S., Alam, M.M., Ahmed, Z., Wong, P.C., Yuen, K.Y. and Woo, P.C.Y. (2016) First genome sequences of buffalo coronavirus from water buffaloes in Bangladesh. New Microbes New Infect., 11: 54-56.

67. Byukusenge, M., Nissly, R.H., Kasibhatla, S.M., Li, L., Russell, R., Springer, H., Barry, R., Van Saun, R., Wolfgang, D., Hovingh, E., Kulkarni-Kale, U. and Kuchipudi, S.V. (2018) Complete genome sequences of four bovine coronavirus isolates from Pennsylvania. Genome Announc., 6(22): 1-2.

68. Papineau, A., Berhane, Y., Wylie, T.N., Wylie, K.M., Sharpe, S. and Lung, O. (2019) Genome organization of Canada goose coronavirus, a novel species identified in a mass die-off of Canada geese. Sci. Rep., 9(1): 5954.

69. Jin, L., Cebra, C.K., Baker, R.J., Mattson, D.E., Cohen, S.A., Alvarado, D.E. and Rohrmann, G.F. (2007), Analysis of the genome sequence of an alpaca coronavirus. Virology, 365(1): 198-203.

70. Woo, P.C.Y., Lau, S.K.P., Wernery, U., Wong, E.Y.M., Tsang, A.K.L., Johnson, B., Yip, C.C.Y., Lau, C.C.Y., Sivakumar, S., Cai, J.P., Fan, R.Y.Y., Chan, K.H., Mareena, R. and Yuen, K.Y. (2014) Novel betacoronavirus in dromedaries of the Middle East, 2013. Emerg. Infect. Dis., 20(4): 560-572.

71. Dominguez, S.R., O'Shea, T.J., Oko, L.M., Holmes, K.V., O'Shea, T.J., Oko, L.M. and Holmes, K.V. (2007) Detection of group 1 coronaviruses in bats in North America. Emerg. Infect. Dis., 13(9): 1295-1300.

72. Benvenuto, D., Giovanetti, M., Ciccozzi, A., Spoto, S., Angeletti, S. and Ciccozzi, M. (2020). The 2019-new coronavirus epidemic: Evidence for virus evolution. J. Med. Virol., 92(4): 455-459.

73. Xu, X., Chen, P., Wang, J., Feng, J., Zhou, H., Li, X., Zhong, W. and Hao, P. (2020) Evolution of the novel coronavirus from the ongoing Wuhan outbreak and modeling of its spike protein for risk of human transmission. Sci. China Life Sci., 63(3): 457-460.

74. Gralinski, L.E. and Menachery, V.D. (2020) Return of the coronavirus: 2019-nCoV. Viruses, 12(2): 135.

75. Tang, X., Wu, C., Li, X., Song, Y., Yao, X., Wu, X., Duan, Y., Zhang, H., Wang, Y., Qian, Z., Cui, J. and Lu, J. (2020) On the origin and continuing evolution of SARS-CoV-2. Natl. 
Sci.Rev., 7(6): 1012-1023.

76. Cooper, S. and Coxe, D. (2005) Learning from SARS: Preparing for the Next Disease Outbreak: Workshop Summary Institute of Medicine, Board on Global Health, Forum on Microbial Threats.

77. Holmes, K.V. (2003) SARS coronavirus: A new challenge for prevention and therapy. J. Clin. Invest., 111(11): 1605-1609.

78. Hui, D.S., Azhar, E.I., Madani, T.A., Ntoumi, F., Kock, R., Dar, O.,Ippolito, G., Mchugh,T.D.,Memish,Z.A.,Drosten,C., Zumla, A. and Petersen, E. (2020) The continuing 2019$\mathrm{nCoV}$ epidemic threat of novel coronaviruses to global health the latest 2019 novel coronavirus outbreak in Wuhan, China. Int. J. Infect. Dis., 91: 264-266.

79. Huang, C., Wang, Y., Li, X., Ren, L., Zhao, J., Hu, Y., Zhang, L., Fan, G., Xu, J., Gu, X. and Cheng, Z. (2020) Clinical features of patients infected with 2019 novel coronavirus in Wuhan, China. Lancet, 395(10223): 497-506.

80. Bolles, M., Donaldson, E. and Baric, R. (2011) SARS-CoV and emergent coronaviruses: Viral determinants of interspecies transmission. Curr. Opin. Virol., 1(6): 624-634.

81. Perlman, S. (2020) Another decade, another coronavirus. $N$. Engl. J. Med., 382(8): 760-762.

82. World Health Organization. (2020) Situation Reports. Available from: https:/www.who.int/docs/default-source/ coronaviruse/situation-reports/20200417.

83. Shi, Y., Yi, Y., Li, P., Kuang, T., Li, L., Dong, M., Ma, Q. and Cao, C. (2003) Diagnosis of severe acute respiratory syndrome (SARS) by detection of SARS coronavirus nucleocapsid antibodies in an antigen-capturing enzymelinked immunosorbent assay. J. Clin. Microbiol., 41(12): 5781-5782.

84. Tian, X., Li, C., Huang, A., Xia, S., Lu, S., Shi, Z., Lu, L., Jiang, S., Yang, Z., Wu, Y. and Ying, T. (2020) Potent binding of 2019 novel coronavirus spike protein by a SARS coronavirus-specific human monoclonal antibody. Emerg. Microb. Infect., 9(1): 382-385.

85. Riou, J. and Althaus, C.L. (2020) Pattern of early humanto-human transmission of Wuhan 2019 novel coronavirus (2019-nCoV), December 2019 to January 2020. Eur. Surveill, 25(4): 1-5.

86. Dong, N., Yang, X., Ye, L., Chen, K., Chan, E.W.C. and Chen, S. (2020) Genomic and protein structure modelling analysis depicts the origin and pathogenicity of $2019-\mathrm{nCoV}$, a new coronavirus which caused a pneumonia outbreak in Wuhan, China. F1000 Res., 9: 121.

87. Coronavirus. (2020) Johns Hopkins Coronavirus Resource Center. Available from:.https://www.coronavirus.jhu.edu/ map.html. Retrieved on 15-04-2021.

88. Plowright, R.K., Parrish, C.R., McCallum, H., Hudson, P.J., Ko, A.I., Graham, A.L. and Lloyd-Smith, J.O. (2017) Pathways to zoonotic spillover. Nat. Rev. Microbiol., 15(8): 502-510

89. Wang, L.F. and Crameri, G. (2014) Emerging zoonotic viral diseases. Rev. Sci. Technol., 33(2): 569-581.

90. Malik, Y.S., Sircar, S., Bhat, S., Sharun, K., Dhama, K., Dadar, M., Tiwari, R. and Chaicumpa, W. (2020) Emerging novel coronavirus (2019-nCoV) current scenario, evolutionary perspective based on genome analysis and recent developments. Vet. Q., 40(1): 68-76.

91. Vijgen, L., Keyaerts, E., Moës, E., Thoelen, I., Wollants, E., Lemey, P., Vandamme, A.M. and Van Ranst, M. (2005), Complete genomic sequence of human coronavirus OC43: Molecular clock analysis suggests a relatively recent zoonotic coronavirus transmission event. J. Virol., 79(3): 1595-1604.

92. Zhang, C., Zheng, W., Huang, X., Bell, E.W., Zhou, X. and Zhang, Y. (2020) Protein structure and sequence reanalysis of 2019-nCoV genome refutes snakes as its intermediate host and the unique similarity between its spike protein insertions and HIV-1. J. Proteome Res., 19(4): 1351-1360.
93. Cheng, Z.J. and Shan, J. (2020) 2019 Novel coronavirus: Where we are and what we know. Infection, 48(2): 155-163.

94. Everard, M., Johnston, P., Santillo, D. and Staddon, C. (2020) The role of ecosystems in mitigation and management of Covid-19 and other zoonoses. Environ. Sci. Policy, 111: 7-17.

95. Khabbaz, R., Bell, B.P., Schuchat, A., Ostroff, S.M., Moseley, R., Levitt, A. and Hughes, J.M. (2015) Emerging and reemerging infectious disease threats. In: Mandell, Douglas, and Bennett's Principles and Practice of Infectious Diseases. Elsevier, Amsterdam, Netherlands. p158.

96. He, G., Sun, Z., Zhao, Y., Zhang, S., Chen, H., Zhao, Z., Yang, G. and Zhou, Q. (2020), $\beta$-coronavirus infectious diseases: Recommended strategies for the prevention and control of transmission. Int. J. Clin. Exp. Pathol., 13(5): 1060 .

97. Jones, B.A., Grace, D., Kock, R., Alonso, S., Rushton, J., Said, M.Y., McKeever, D., Mutua, F., Young, J., McDermott, J. and Pfeiffer, D.U. (2013) Zoonosis emergence linked to agricultural intensification and environmental change. Proc. Natl. Acad. Sci., 110(21): 8399-8404.

98. Keesing, F., Belden, L.K., Daszak, P., Dobson, A., Harvell, C.D., Holt, R.D., Hudson, P., Jolles, A., Jones, K.E., Mitchell, C.E. and Myers, S.S. (2010) Impacts of biodiversity on the emergence and transmission of infectious diseases. Nature, 468(7324): 647-652.

99. Sollund, R.A. (2019) The Crimes of Wildlife Trafficking: Issues of Justice, Legality and Morality. Routledge, Milton Park.

100. Beirne, P. (2021) Wildlife trade and COVID-19: Towards a criminology of anthropogenic pathogen spillover. $B r . J$. Criminol., 61(3): 607-626.

101. Ye, Z.W., Yuan, S., Yuen, K.S., Fung, S.Y., Chan, C.P. and Jin, D.Y. (2020) Zoonotic origins of human coronaviruses. Int. J. Biol. Sci., 16(10): 1686.

102. Aguirre, A.A., Catherina, R., Frye, H. and Shelley, L. (2020) Illicit wildlife trade, wet markets, and COVID-19: Preventing future pandemics. World Med. Health Policy, 12(3): 256-265.

103. Ng, L.F. and Hiscox, J.A. (2020) Coronaviruses in animals and humans. BMJ, 368: $\mathrm{m} 634$.

104. Hosie, M.J., Hartmann, K., Hofmann-Lehmann, R., Addie, D.D., Truyen, U. and Egberink, H. (2020) SARSCoronavirus (CoV)-2 and cats. European Advisory Board on Cat Diseases, 23 Apr 2020.

105. ProMED-mail. (2021) $\mathrm{PRO} / \mathrm{AH} / \mathrm{EDR}>\mathrm{COVID}-19$ Update (469): USA (TN) Animal, Zoo, Tiger. Available from: https://www.promedmail.org/promed-post/?id=7915683. Retrieved on 10-11-2020.

106. Oreshkova, N., Molenaar, R.J., Vreman, S., Harders, F., Munnink, B.B.O., Hakze-van Der Honing, R.W., Gerhards, N., Tolsma, P., Bouwstra, R., Sikkema, R.S. and Tacken, M.G. (2020) SARS-CoV-2 infection in farmed minks, the Netherlands, April and May 2020. Euro Surveill., 25(23): 2001005.

107. Shi, J., Wen, Z., Zhong, G., Yang, H., Wang, C. and Huang, B. (2020) Susceptibility of ferrets, cats, dogs, and other domesticated animals to SARS-coronavirus 2. Science, 368(6494): 1016-1020.

108. Shan, C., Yao, Y.F., Yang, X.L., Zhou, Y.W., Wu, J. and Gao, G. (2020) Infection with novel coronavirus (SARSCoV-2) causes pneumonia in the rhesus macaques. Cell Res., 30: 670-677.

109. Sia, S.F., Yan, L.M., Chin, A.W.H., Fung, K., Choy, K.T. and Wong, A.Y.L. (2020) Pathogenesis and transmission of SARS-CoV-2 in golden hamsters. Nature, 583(7818): 834-838.

110. Kim, Y.I., Kim, S.G., Kim, S.M., Kim, E.H., Park, S.J. and Yu, K.M. (2020) Infection and rapid transmission of SARSCoV-2 in Ferrets. Cell Host Microbe, 27(5): 704-709.e2.

111. Chan, J.F., Zhang, A.J., Yuan, S., Poon, V.K., Chan, C.C. and Lee, A.C. (2020) Simulation of the clinical and pathological 
manifestations of Coronavirus Disease 2019 (COVID-19) in golden Syrian hamster model: Implications for disease pathogenesis and transmissibility. Clin. Infect. Dis., 71(9): 2428-2446.

112. Hasan, A., Paray, B.A., Hussain, A., Qadir, F.A., Attar, F.,
Aziz, F.M., Sharifi, M., Derakhshankhah, H., Rasti, B., Mehrabi, M. and Shahpasand, K. (2020) A review on the cleavage priming of the spike protein on coronavirus by angiotensin-converting enzyme-2 and furin. J. Biomol. Struct. Dyn., 39(8): 3025-3033.

$* * * * * * * *$ 